\title{
Bacillus qingdaonensis sp. nov., a moderately haloalkaliphilic bacterium isolated from a crude sea-salt sample collected near Qingdao in eastern China
}

Correspondence Guang-Qin Guo gqguo@|zu.edu.cn

\author{
Qian-fu Wang, Wei Li, Yan-li Liu, Hai-hua Cao, Zhao Li \\ and Guang-qin Guo
}

\author{
Institute of Cell Biology, School of Life Sciences, Lanzhou University, Lanzhou 730000, \\ People's Republic of China
}

\begin{abstract}
A moderately haloalkaliphilic, Gram-positive bacterium, designated as strain $\mathrm{CM} 1^{\top}$, was isolated from a crude sea-salt sample collected near Qingdao in eastern China. Strain $\mathrm{CM} 1^{\top}$ was found to grow optimally at $37^{\circ} \mathrm{C}$ and $\mathrm{pH}$ 9.0. It was shown to be aerobic, rod-shaped and capable of

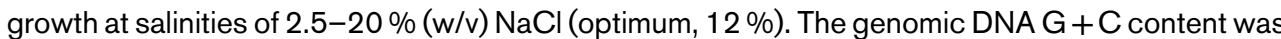
about $48 \mathrm{mo} \%$. The major cellular fatty acids were anteiso- $\mathrm{C}_{15: 0}$, anteiso- $\mathrm{C}_{17: 0}$ and iso- $\mathrm{C}_{16: 0}$ and the major isoprenoid quinones were $\mathrm{MK}-7\left(\mathrm{H}_{2}\right)$ and $\mathrm{MK}-6\left(\mathrm{H}_{2}\right)$. Phylogenetic analyses based on 16S rRNA gene sequences revealed that $\mathrm{CM}^{\top}{ }^{\top}$ is a member of the genus Bacillus and has less than $95.2 \%$ gene sequence similarity to the most closely related strain, Bacillus salarius $\mathrm{BH} 169^{\top}$. Its DNA-DNA reassociation value with respect to $B$. salarius $\mathrm{BH} 169^{\top}$ was $35.4 \%$. On the basis of phenotypic and molecular properties, strain $\mathrm{CM}^{\top}{ }^{\top}$ represents a novel Bacillus species, for which the name Bacillus qingdaonensis sp. nov. is proposed. The type strain is $\mathrm{CM}^{\top}{ }^{\top}$ ( = CGMCC $\left.1.6134^{\top}=\mathrm{JCM} 14087^{\top}\right)$.
\end{abstract}

The genus Bacillus is a large taxonomic group containing species of many different physiological types. Among these, aerobic and halophilic rods have been isolated from a wide range of saline habitats, such as salt lakes, sea ice, salterns, salty foods, estuarine water and deep-sea hydrothermal vents (Agnew et al., 1995; Arahal et al., 1999; Lim et al., 2006; Nielsen et al., 1994; Ventosa et al., 1989; Yoon et al., 2004). Because of their potential usefulness in the production of compatible solutes or hydrolytic enzymes (Margesin \& Schinner, 2001), alkaline enzymes (Horikoshi, 1971), cyclomaltodextrin glucanotransferase (CGTase) (Yamamoto et al., 1972) and cellulase (Horikoshi et al., 1971), this group of bacteria has attracted a great deal of attention recently.

While screening halophilic bacteria from a crude sea-salt sample collected near Qingdao in eastern China, we isolated an aerobic, Gram-positive, moderately halophilic bacterium, designated as strain $\mathrm{CM}^{\mathrm{T}}$. On the basis of its

The GenBank/EMBL/DDBJ accession number for the $16 \mathrm{~S}$ rRNA gene sequence of strain $\mathrm{CM}^{\top}{ }^{\top}$ is $\mathrm{DQ} 115802$.

Phylogenetic trees based on maximum-parsimony and minimumevolution analyses of the $16 \mathrm{~S}$ rRNA gene sequences of strain $\mathrm{CM} 1^{\top}$ and related species are available as supplementary figures in IJSEM Online. phenotypic characteristics and genotypic data, this strain should be assigned to the genus Bacillus as a novel species.

CM medium (Seghal \& Gibbons, 1960) at pH 7.0 and containing $12 \%(\mathrm{w} / \mathrm{v}) \mathrm{NaCl}$ was used for bacterial enrichment and growth. The sample was first inoculated into the liquid medium and cultured on a shaker (120 r.p.m.) at $37^{\circ} \mathrm{C}$ in the dark until turbid, then streaked onto solid medium to obtain single colonies. The streaking was repeated several times to obtain pure single colonies. The purified strain was cultured and maintained in liquid or solid ATCC 213 medium (Garrity et al., 2004) at pH 7.0, with $12 \%(\mathrm{w} / \mathrm{v}) \mathrm{NaCl}$, in the dark.

Cell morphology was determined by using phase-contrast microscopy. Gram staining was performed according to Dussault (1955) and electron microscopy was performed with negative staining according to Bouchotroch et al. (2001).

Bacterial growth was determined by measuring absorbance at $660 \mathrm{~nm}$ at certain intervals during liquid culture. The effects of different concentrations of $\mathrm{NaCl}$ on the growth of strain $\mathrm{CM1}^{\mathrm{T}}$ were tested in liquid ATCC 213 medium by measuring the absorbance at $660 \mathrm{~nm}$ after 7 days incubation.

The susceptibility of strain $\mathrm{CM}^{\mathrm{T}}$ to different antibiotics, including ampicillin, tetracycline, hygromycin, kanamycin, 

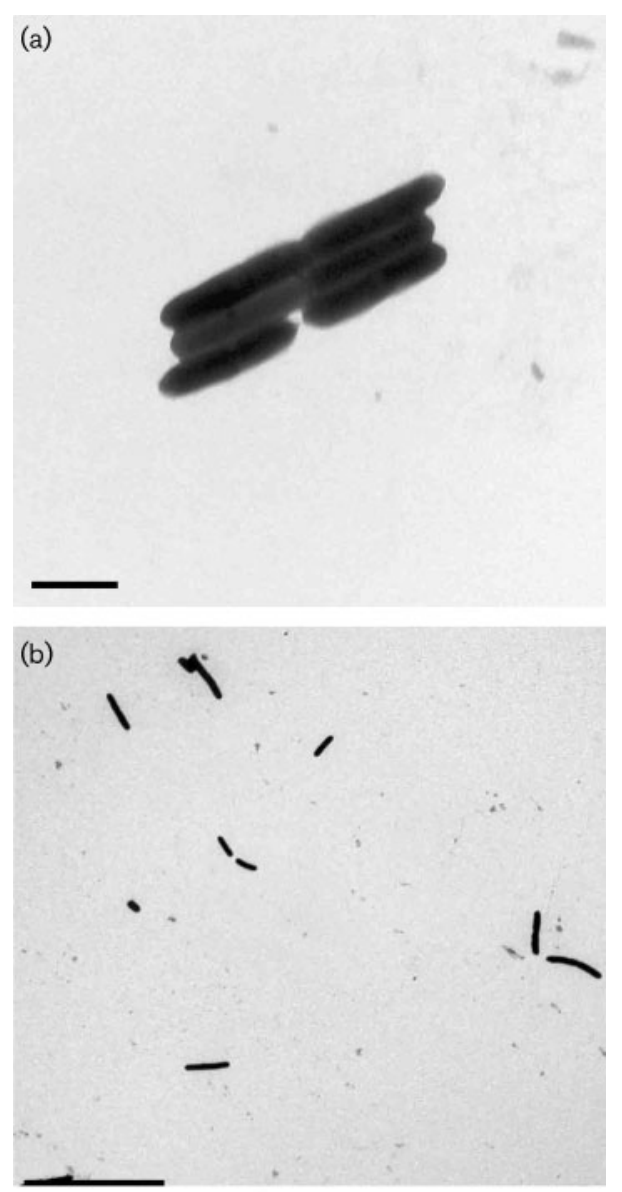

(c)

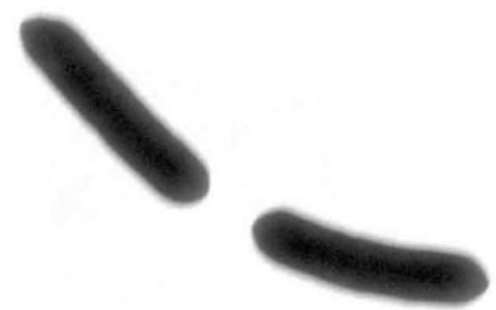

Fig. 1. Transmission electron micrographs of cells of strain $\mathrm{CM} 1^{\top}$. Bars, $1 \mu \mathrm{m}(\mathrm{a}, \mathrm{c}), 10 \mu \mathrm{m}(\mathrm{b})$.

streptomycin, rifampicin, bacitracin, penicillin, chloramphenicol, neomycin and erythromycin (Sigma) was tested on solid ATCC 213 medium after 7 days incubation at $37^{\circ} \mathrm{C}$. Analysis of the whole-cell fatty acid pattern was performed according to previously described methods (Miller, 1982) using the Sherlock system (MIDI). Isoprenoid quinones were analysed by HPLC with a reversed-phase column according to the method of Komagata \& Suzuki (1987).
Physiological and biochemical tests were performed as described by Buchanan \& Gibbons (1974) and Dong \& Cai (2001). Anaerobic growth of strain $\mathrm{CM}^{\mathrm{T}}$ with nitrate as the electron acceptor was tested according to the method of Mancinelli \& Hochstein (1986). Growth with DMSO and by the fermentation of L-arginine as alternative electron acceptors was tested as described by Oren et al. (1997) and Oren \& Trüper (1990) using closed tubes fully filled with the growth medium and then kept in the dark for 3 weeks before comparison of the growth with that found on medium lacking the test compounds. The DNA G $+\mathrm{C}$ content was determined by the thermal denaturation method (Sly et al., 1986) using a Beckman UV-800 spectrophotometer equipped with a TB-85 thermostat. We used the optical renaturation method (De Ley et al., 1970; Huß et al., 1983; Jahnke, 1992) to perform DNA-DNA hybridization experiments.

PCR amplification of the 16S rRNA gene was performed according to Reddy et al. (2003). The PCR product was ligated to the T-vector and transformed into Escherichia coli JM109 for purification and sequencing.

The sequences used for comparison with the 16S rRNA gene sequence from strain $\mathrm{CM}^{\mathrm{T}}$ were obtained from GenBank by using the BLAST program. The sequence from strain $\mathrm{CM}^{\mathrm{T}}$ was aligned with closely related $16 \mathrm{~S}$ rRNA gene sequences using CLUSTAL_X software (version 1.83; Thompson et al.,

Table 1. Fatty acid content (\% of total fatty acids) of strain $\mathrm{CM} 1^{\top}$

\begin{tabular}{|lc|}
\hline Fatty acid & Content (\%) \\
\hline $\mathrm{C}_{12: 0}$ & 0.05 \\
$\mathrm{C}_{14: 0}$ & 1.29 \\
$\mathrm{C}_{14: 0} 2-\mathrm{OH}$ & 0.23 \\
$\mathrm{C}_{15: 0}$ & 1.22 \\
$\mathrm{C}_{15: 1} \omega 6 c$ & 0.10 \\
$\mathrm{C}_{16: 0}$ & 7.72 \\
$\mathrm{C}_{16: 1} \omega 7 c$ & 0.82 \\
$\mathrm{C}_{17: 0}$ & 0.72 \\
$\mathrm{C}_{18: 0}$ & 2.12 \\
$\mathrm{C}_{18: 1} \omega 9 c$ & 0.94 \\
$\mathrm{C}_{18: 1} \omega 7 c$ & 0.87 \\
$\mathrm{C}_{16: 1} \omega 7 c$ alcohol & 0.17 \\
anteiso- $\mathrm{C}_{13: 0}$ & 0.17 \\
iso- $\mathrm{C}_{14: 0}$ & 1.63 \\
iso- $\mathrm{C}_{14: 0} 3-\mathrm{OH}$ & 0.21 \\
iso- $\mathrm{C}_{15: 0}$ & 5.88 \\
anteiso- $\mathrm{C}_{15: 0}$ & 34.78 \\
iso- $\mathrm{C}_{15: 1} \mathrm{I}$ & 0.50 \\
anteiso- $\mathrm{C}_{15: 1} \mathrm{~A}$ & 0.31 \\
iso- $\mathrm{C}_{16: 0}$ & 13.99 \\
anteiso- $\mathrm{C}_{17}: 0$ & 21.43 \\
iso- $\mathrm{C}_{17: 0}$ & 4.38 \\
iso- $\mathrm{C}_{18: 0}$ & 0.38 \\
iso- $\mathrm{C}_{19: 0}$ & 0.10 \\
& \\
\hline
\end{tabular}


Table 2. Differential characteristics of strain $\mathrm{CM} 1^{\top}$ and closely related strains

Strains: 1, CM1 ${ }^{\mathrm{T}}$; 2, B. salarius DSM $16461^{\mathrm{T}}$ (data from Lim et al., 2006); 3, Bacillus saliphilus DSM 15402 ${ }^{\mathrm{T}}$ (Romano et al., 2005); 4 , Bacillus clarkii DSM $8720^{\mathrm{T}}$ (Nielsen et al., 1995). +, Positive; - , negative; NR, not reported; w, weakly positive. All strains are positive for the Gram reaction and negative for the hydrolysis of starch and anaerobic growth.

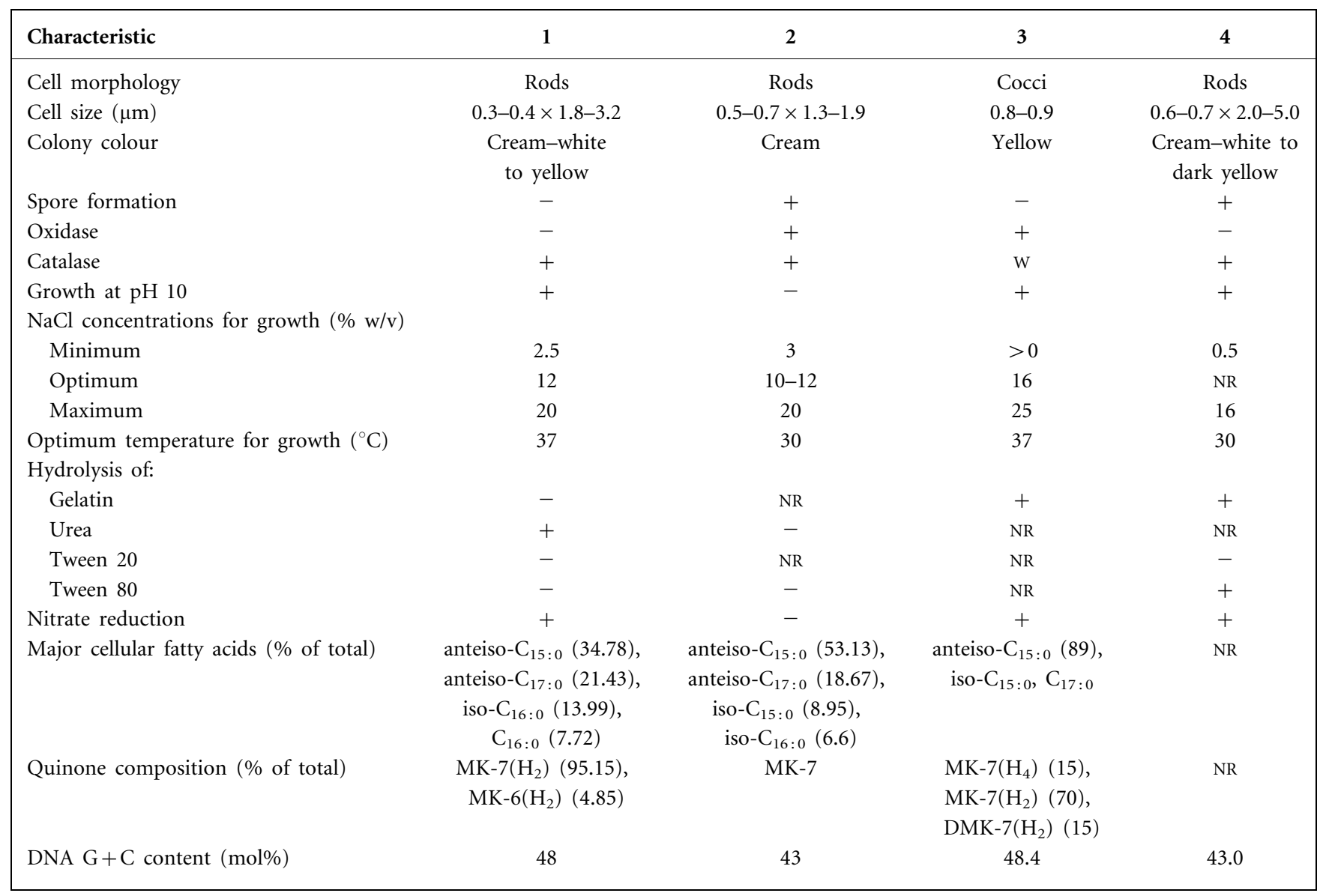

1997). The phylogenetic tree was constructed by using neighbour-joining (Saitou \& Nei, 1987), maximumparsimony and minimum-evolution methods in MEGA, version 3.1 (Kumar et al., 2001, 2004). The confidence values for the branches of the phylogenetic tree were determined using bootstrap analyses (Felsenstein, 1985) based on 1000 resamplings.

Cells of strain $\mathrm{CM}^{\mathrm{T}}$ were Gram-positive rods, 0.3-0.4 $\mu \mathrm{m}$ wide and 1.8-3.2 $\mu \mathrm{m}$ long (Fig. 1). The colonies were cream-white to yellow in colour, wet and smooth-surfaced with clear edges on ATCC 213 medium containing $12 \%$ $(\mathrm{w} / \mathrm{v}) \mathrm{NaCl}$. Strain $\mathrm{CM}^{\mathrm{T}}$ grew as single cells or clusters (Fig. 1). The novel strain did not produce spores, even in the presence of $0.1 \mathrm{~g} \mathrm{MnCl}_{2} \mathrm{ml}^{-1}$ and under other conditions used for stimulating spore formation (Hageman et al., 1984).

Strain $\mathrm{CM}^{\mathrm{T}}$ grew at salt concentrations in the range 2.5$20 \%(\mathrm{w} / \mathrm{v}) \mathrm{NaCl}, 12 \%$ being the optimum concentration. It grew at $\mathrm{pH} 6.5-10.5$ in $12 \%(\mathrm{w} / \mathrm{v}) \mathrm{NaCl}, \mathrm{pH} 9.0$ being the optimum. The permissive temperature for growth was between 25 and $45^{\circ} \mathrm{C}$, the optimum value being $37^{\circ} \mathrm{C}$.
Growth of strain $\mathrm{CM}^{\mathrm{T}}$ could be inhibited by the antibiotics rifampicin, penicillin, hygromycin, ampicillin and bacitracin. No inhibition was observed when the strain was grown in the presence of kanamycin, erythromycin, streptomycin, tetracycline, chloramphenicol or neomycin.

The major fatty acids of strain $\mathrm{CM}^{\mathrm{T}}$ were anteiso- $\mathrm{C}_{15: 0}$, anteiso- $\mathrm{C}_{17: 0}$ and iso- $\mathrm{C}_{16: 0}$; the fatty acid profile is shown in Table 1. The major isoprenoid quinones were $\mathrm{MK}-7\left(\mathrm{H}_{2}\right)$ $(95.15 \%)$ and MK-6( $\left.\mathrm{H}_{2}\right)(4.85 \%)$.

A comparison of the phenotypic and physiological properties of strain $\mathrm{CM}^{\mathrm{T}}$ with those of the type strains of three closely related Bacillus species is shown in Table 2. Strain $\mathrm{CM}^{\mathrm{T}}$ had a DNA $\mathrm{G}+\mathrm{C}$ content of $48 \mathrm{~mol} \%$ and had a DNA-DNA reassociation value of $35.4 \%$ with Bacillus salarius $\mathrm{BH} 169^{\mathrm{T}}$.

The full sequence (1572 bases) of the 16S rRNA gene of strain $\mathrm{CM}^{\mathrm{T}}$ was determined. The $16 \mathrm{~S}$ rRNA gene phylogenetic analysis showed that strain $\mathrm{CM}^{\mathrm{T}}$ was most similar to $B$. salarius $\mathrm{BH} 169^{\mathrm{T}}(95.2 \%)$. The sequence similarities 


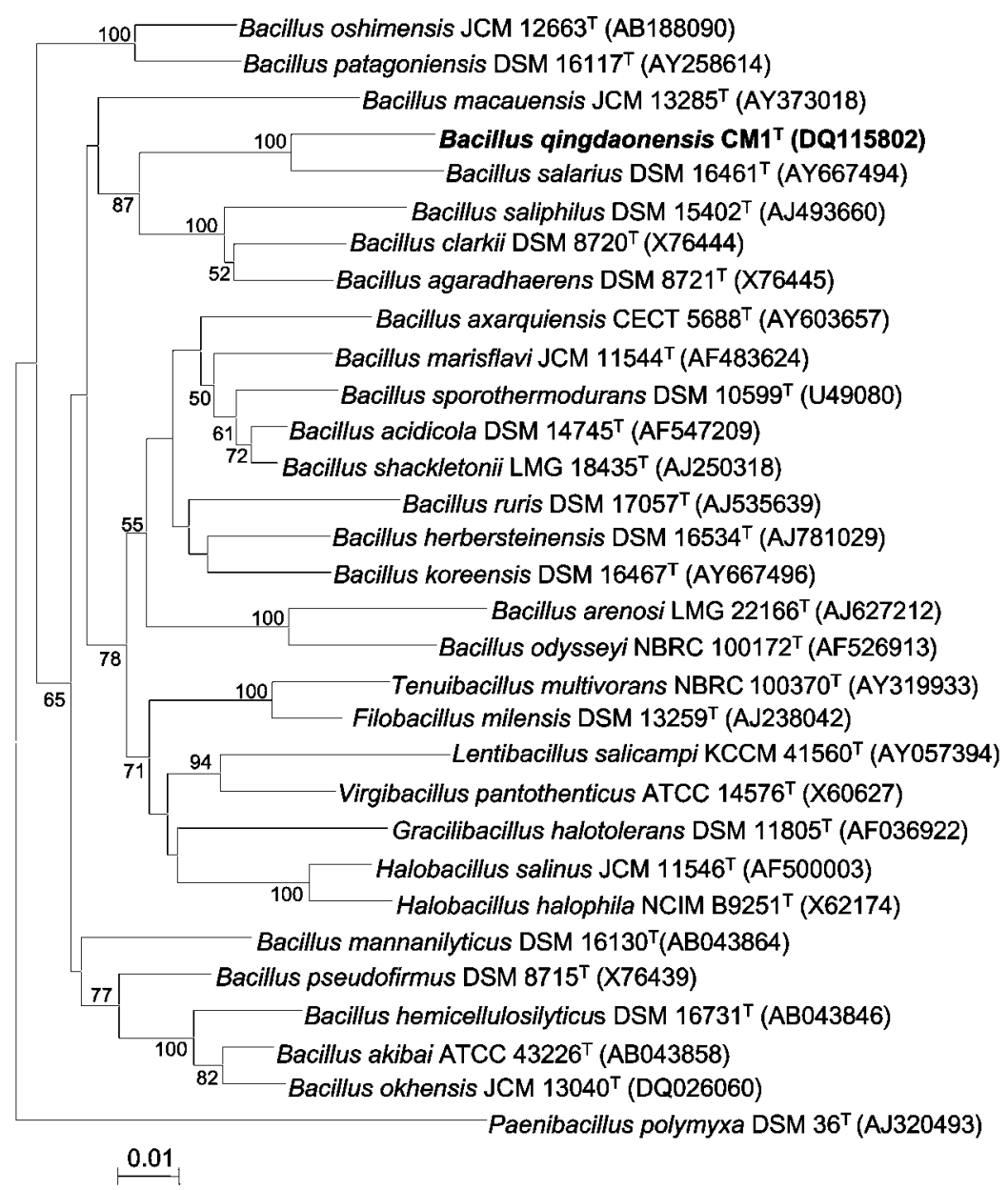

Fig. 2. Neighbour-joining phylogenetic tree, based on 16S rRNA gene sequences, showing the relationships of strain $\mathrm{CM}^{\top}$ and the type strains of related taxa. Paenibacillus polymyxa was used as an outgroup. Bootstrap percentages (based on 1000 replicates) greater than $50 \%$ are shown at branch points. Bar, 0.01 changes per nucleotide position. with respect to other Bacillus species with validly published names were below $91.6 \%$. Evaluation of the tree topology showed that strain $\mathrm{CM}^{\mathrm{T}}$ forms a branch with $B$. salarius BH169 ${ }^{\mathrm{T}}$ (Fig. 2 and Supplementary Figs $\mathrm{S} 1$ and S2 available in IJSEM Online).

In summary, our molecular phylogenetic analysis and phenotypic characterization of strain $\mathrm{CM}^{\mathrm{T}}$ clearly show that this strain is distinguishable from closely related species within the genus Bacillus (Table 1). In conclusion, strain $\mathrm{CM}^{\mathrm{T}}$ represents a novel species of the genus Bacillus, for which the name Bacillus qingdaonensis sp. nov. is proposed.

\section{Description of Bacillus qingdaonensis sp. nov.}

Bacillus qingdaonensis (qing.da.o.nen'sis. N.L. masc. adj. qingdaonensis pertaining to Qingdao, the name of the place from which the type strain was isolated).

Cells are rod-shaped, $0.3-0.4 \times 1.8-3.2 \mu \mathrm{m}$ and Grampositive. Colonies are cream-white to yellow, smooth and circular. Aerobic, non-spore-forming and non-motile (nonflagellated). Grows at $25-45^{\circ} \mathrm{C}$ and at $2.5-20 \%(\mathrm{w} / \mathrm{v}) \mathrm{NaCl}$, with optima around $37^{\circ} \mathrm{C}$ and $12 \%(\mathrm{w} / \mathrm{v}) \mathrm{NaCl}$. The $\mathrm{pH}$ range for growth is 6.5-10.5 in $12 \%(\mathrm{w} / \mathrm{v}) \mathrm{NaCl}$ (optimum,
pH 9.0). Oxidase-negative and catalase-positive. Negative for hydrolysis of soluble starch, gelatin and Tweens 20 and 80 and for production of $\mathrm{H}_{2} \mathrm{~S}$ and indole. Positive for hydrolysis of urea and arginine and for nitrate reduction. Utilizes, and produces acid, from sucrose, D-glucose, Dfructose, D-galactose, cellobiose, D-mannose, D-mannitol, D-galactose, lactose, D-xylose and dextran as sole carbon sources. Voges-Proskauer and methyl red reactions are negative. The major fatty acids are anteiso- $\mathrm{C}_{15: 0}$, anteiso$\mathrm{C}_{17: 0}$ and iso- $\mathrm{C}_{16: 0}$. The major isoprenoid quinones are MK-7 $\left(\mathrm{H}_{2}\right)$ and MK-6 $\left(\mathrm{H}_{2}\right)$. The DNA G $+\mathrm{C}$ content of the type strain is $48 \mathrm{~mol} \%$.

The type strain, $\mathrm{CM}^{\mathrm{T}}\left(=\mathrm{CGMCC} 1.6134^{\mathrm{T}}=\mathrm{JCM} 14087^{\mathrm{T}}\right.$ ), was isolated from a crude sea-salt sample collected near Qingdao in eastern China.

\section{Acknowledgements}

This work was supported by the National Science Foundation of China (NSFC 30270134). We are indebted to Dr Wen-Jun Li (Yunnan University, China) and Professor Pi-Jin Zhou (Institute of Microbiology, Chinese Academy of Sciences) for their excellent technical assistance in the determination of DNA G $+C$ contents. 


\section{References}

Agnew, M. D., Koval, S. F. \& Jarrell, K. F. (1995). Isolation and characterization of novel alkaliphiles from bauxite-processing waste and description of Bacillus vedderi sp. nov., a new obligate alkaliphile. Syst Appl Microbiol 18, 221-230.

Arahal, D. R., Marquez, M. C., Volcani, B. E., Schleifer, K.-H. \& Ventosa, A. (1999). Bacillus marismortui sp. nov., a new moderately halophilic species from the Dead Sea. Int J Syst Bacteriol 49, 521-530.

Bouchotroch, S., Quesada, E., del Moral, A., Llamas, I. \& Bejar, V. (2001). Halomonas maura sp. nov., a novel moderately halophilic, exopolysaccharide-producing bacterium. Int J Syst Evol Microbiol 51, $1625-1632$.

Buchanan, R. G. \& Gibbons, N. E. (1974). Bergey's Manual of Determinative Bacteriology, 8th edn, pp. 269-272. Baltimore: Williams \& Wilkins.

De Ley, L., Cattoir, H. \& Reynaerts, A. (1970). Quantitative measurement of DNA hybridization from renaturation rates. Eur J Biochem 12, 133-142.

Dong, X. Z. \& Cai, M. Y. (2001). Manual of the Identification of General Bacteria. Beijing: Scientific Press.

Dussault, H. P. (1955). An improved technique for staining red halophilic bacteria. J Bacteriol 70, 484-485.

Felsenstein, J. (1985). Confidence limits on phylogenies: an approach using the bootstrap. Evolution 39, 783-791.

Garrity, G. M., Bell, J. A. \& Lilburn, T. G. (2004). Taxonomic outline of the prokaryotes. In Bergey's Manual of Systematic Bacteriology, 2nd edn, Release 5.0. New York: Springer. http://141.150.157.80/ bergeysoutline/main.htm

Hageman, J. H., Shankweiler, G. W., Wall, P. R., Franich, K., McCowan, G. W., Cauble, S. M., Grajeda, J. \& Quinones, C. (1984). Single, chemically defined sporulation medium for Bacillus subtilis: growth, sporulation, and extracellular protease production. J Bacteriol 160, 438-441.

Horikoshi, K. (1971). Production of alkaline enzymes by alkalophilic microorganisms. Part I. Alkaline protease produced by Bacillus no. 221. Agric Biol Chem 36, 1407-1414.

Horikoshi, K., Ikeda, Y. \& Nakao, M. (1971). Manufacturing method of cellulase. Japan patent no. 46-76685.

Huß, V. A. R., Festl, H. \& Schleifer, K.-H. (1983). Studies on the spectrophotometric determination of DNA hybridization from renaturation rates. Syst Appl Microbiol 4, 184-192.

Jahnke, K.-D. (1992). Basic computer program for evaluation of spectroscopic DNA renaturation data from GILFORD SYSTEM 2600 spectrophotometer on a PC/XT/AT type personal computer. J Microbiol Methods 15, 61-73.

Komagata, K. \& Suzuki, K. (1987). Lipid and cell-wall analysis in bacterial systematics. Methods Microbiol 19, 161-208.

Kumar, S., Tamura, K., Jakobson, I. B. \& Nei, M. (2001). MEGA2: molecular evolutionary genetics analysis software. Bioinformatics 17, 1244-1245.

Kumar, S., Tamura, K., Jakobson, I. B. \& Nei, M. (2004). MEGA3: integrated software for molecular evolutionary genetics analysis and sequence alignment. Brief Bioinform 5, 150-163.
Lim, J.-M., Jeon, C.-O., Lee, S.-M., Lee, J.-C., Xu, L.-H., Jiang, C.-L. \& Kim, C.-J. (2006). Bacillus salarius sp. nov., a halophilic, sporeforming bacterium isolated from a salt lake in China. Int J Syst Evol Microbiol 56, 373-377.

Mancinelli, R. L. \& Hochstein, L. I. (1986). The occurrence of denitrification in extremely halophilic bacteria. FEMS Microbiol Lett 35, 55-58.

Margesin, R. \& Schinner, F. (2001). Potential of halotolerant and halophilic microorganisms for biotechnology. Extremophiles 5, 73-83.

Miller, L. T. (1982). Single derivatization method for routine analysis of bacterial whole-cell, fatty acid methyl esters, including hydroxyl acids. J Clin Microbiol 16, 584-586.

Nielsen, P., Rainey, F. A., Outtrup, H., Priest, F. G. \& Fritze, D. (1994). Comparative $16 \mathrm{~S}$ rDNA sequence analysis of some alkaliphilic bacilli and the establishment of a sixth rRNA group within the genus Bacillus. FEMS Microbiol Lett 117, 61-66.

Nielsen, P., Fritze, D. \& Priest, F. G. (1995). Phenetic diversity of alkaliphilic Bacillus strains: proposal for nine new species. Microbiology 141, 1745-1761.

Oren, A. \& Trüper, H. G. (1990). Anaerobic growth of halophilic archaeobacteria by reduction of dimethylsufoxide and trimethylamine N-oxide. FEMS Microbiol Lett 70, 33-36.

Oren, A., Ventosa, A. \& Grant, W. D. (1997). Proposed minimal standards for description of new taxa in the order Halobacteriales. Int J Syst Bacteriol 47, 233-238.

Reddy, G. S. N., Raghavan, P. U. M., Sarita, N. B., Prakash, J. S. S., Narayana, N., Daniel, D. \& Shivaji, S. (2003). Halomonas glaciei sp. nov. isolated from fast ice of Adelie Land, Antarctica. Extremophiles 7, 55-61.

Romano, L., Lama, L., Nicolaus, B., Gambacorta, A. \& Giordano, A. (2005). Bacillus saliphilus sp. nov., isolated from a mineral pool in Campania, Italy. Int J Syst Evol Microbiol 55, 159-163.

Saitou, N. \& Nei, M. (1987). The neighbor-joining method: a new method for reconstructing phylogenetic trees. Mol Biol Evol 4, 406-425.

Seghal, S. N. \& Gibbons, N. E. (1960). Effect of some metal ions on the growth of Halobacterium cutirubrum. Can J Microbiol 6, 165-169.

Sly, L. I., Blackall, L. L., Kraat, P. C., Tian-Shen, T. \& Sangkhobol, V. (1986). The use of second derivative plots for the determination of mol\% guanine plus cytosine of DNA by the thermal denaturation method. J Microbiol Methods 5, 139-156.

Thompson, J. D., Gibson, T. J., Plewniak, K., Jeanmougin, F. \& Higgins, D. G. (1997). The CLUSTAL_X windows interface: flexible strategies for multiple sequence alignment aided by quality analysis tools. Nucleic Acids Res 25, 4876-4882.

Ventosa, A., Garcia, M. T., Kamekura, M., Onishi, H. \& RuizBerraquero, F. (1989). Bacillus halophilus sp. nov., a moderately halophilic Bacillus species. Syst Appl Microbiol 12, 162-165.

Yamamoto, M., Tanaka, Y. \& Horikoshi, K. (1972). Alkaline amylases of alkalophilic bacteria. Agric Biol Chem 36, 1819-1823.

Yoon, J.-H., Kim, I.-G., Kang, K.-H., Oh, T.-K. \& Park, Y.-H. (2004) Bacillus hwajinpoensis sp. nov. and an unnamed Bacillus genomospecies, novel members of Bacillus rRNA group 6 isolated from sea water of the East Sea and the Yellow Sea in Korea. Int J Syst Evol Microbiol 54, 803-808. 